\title{
Reverse transcriptase activity in psoriatic lesions: effects of reverse transcriptase inhibitors on keratinocyte proliferation and differentiation
}

\author{
Jean-Pierre Molès*1, Anne Tesniere ${ }^{1}$, Marc Dumas², Frédéric Bonté2 and J- \\ J Guilhou $^{1}$
}

Address: ${ }^{1}$ CNRS-UMR 5247, Montpellier, France and ${ }^{2}$ LVMH Recherche, Saint Jean de Braye, France

* Corresponding author

from Frontiers of Retrovirology: Complex retroviruses, retroelements and their hosts

Montpellier, France. 2I-23 September 2009

Published: 24 September 2009

Retrovirology 2009, 6(Suppl 2):P60 doi:I0.1 186/I742-4690-6-S2-P60

This abstract is available from: http://www.retrovirology.com/content/6/S2/P60

(c) 2009 Molès et al; licensee BioMed Central Ltd.

About half of the human genome is composed of ancient transposable elements that integrated the genome through out the evolution. In order to evaluate whether retroelements could be active in the psoriatic lesion, we 1/ quantified endogenous reverse transcriptase (RT) activity, 2/localised RT-expressing cells 3/evaluated the effects of RT inhibitors on keratinocyte proliferation and differentiation in a skin culture model.

An increased RT activity was detected in protein extracts from lesional psoriatic skin when compared to normal skin (mean $\mathrm{Mn}^{2+}$-dependent RT activity $191 \pm 118 \mu \mathrm{U} / \mathrm{ml}$ $(\mathrm{n}=24)$ vs $71 \pm 78 \mu \mathrm{U} / \mathrm{ml}(\mathrm{n}=17)$ and mean $\mathrm{Mg}^{2+}$ dependent RT activity $7.3 \pm 4.3 \mathrm{mg} / \mathrm{ml}(\mathrm{n}=15)$ vs $2.3 \pm$ $1.93 \mathrm{mg} / \mathrm{ml}(\mathrm{n}=15) ; \mathrm{p}=0.0048$ and $\mathrm{p}=0.0009$, respectively). Sera and plasma from healthy and psoriatic individuals were all negative.

By anti-RT antibody staining, we detected few dermal positive cells in normal skin sections $(\mathrm{n}=10)$ as in nonlesional psoriatic skin $(\mathrm{n}=10)$. In contrast, in the lesional skin $(n=20)$, the granular layer was intensely stained as were Munro's abscesses. In addition, a subset of inflammatory cells was also positive.

In order to evaluate the effects of two RT inhibitors, AZT and Efavirenz, on keratinocyte proliferation and differentiation, we first confirmed the expression of RT proteins in the granular layer of in vitro skin culture. We observed that Efavirenz at $10^{-5} \mathrm{M}$ potently reduced cell proliferation and hyperkeratosis while AZT had little or no effect on keratinocyte differentiation.

These results support that endogenous retroelements are active in the psoriatic lesion and that they also participate in the control of keratinocyte proliferation and differentiation. 